MARKETING AND BRANDING
RESEARCH $\begin{gathered}\text { INDUSTRIAL } \\ \text { MANAGEMENT } \\ \text { INSTITUTE }\end{gathered}$

\title{
Creative industries value chain: The value chain logic in supply chain relationships
}

\author{
Emilia Madudová
}

Univerzitná 8215/1, 01026 Žilina, Slovak Republic

\begin{abstract}
Keywords:

Value Chain, Supply

Chain, Creative

Industry

Correspondence:

Emilia.Madudova@fpedas.

uniza.sk

The purpose of this paper is to provide a deeper look into value chain logic in supply chain relationships in a creative industries value chains. In recent years, value has been recognized as a key factor in better understanding of consumer behavior and gaining a competitive advantage. In a value chain, added value should be defined at every step of the chain. There should be defined activity which adds value as well as the activity that subtracts any value. The total value can be then calculated as the sum of the total value built up all throughout the value chain. Paper mostly analyses creative industries of advertising, architecture, and design. The presented model describes and analyzes the industry participants, value chain processes, support and related environment, and evaluates the relationship of stakeholders. The paper also takes into account the creation of value chain approach that describes the vertical and horizontal linkages. The chain of values represents the coordinated set of kinds of activity which create value for the enterprise, beginning from initial sources of raw materials for suppliers of this enterprise up to the finished goods delivered to the end user including service of the consumer. The value chain conception is important for the identification and development of the enterprise. The value creation activities can be a core competitive advantage which center on fostering relationships with key actors who can derive benefits from each other's value chain.
\end{abstract}

(C)AIMI Journals

\section{Introduction}

Value chain methodology is useful tool to conduct competitive advantage and formulate competitive strategy as mentioned in Štofková, Madleňák, and Štofková Repková (2015) and Štofko, Šoltés, \& Štofková (2015). To define the value in a value chain is not only useful for an competitive strategy but it is beneficial for future decision making as well. Cultural 
products carry strong symbolic value which is determined by the social and cultural meanings accosiated with it that permit consumers to convey individual and social identity via the purchase and use of the product (Plangger, 2016). In recent years, culture and creative industries were found as a useful tool for new demand sources and for this reason they play an important role in the national development policies in many countries. Culture or creative industry can be both high-tech and high-touch, highly creative, and with potentials in economic development (Eikhof \& Hauschild, 2007).

\section{Innovations due to Close Ties to Customers and Users}

Cultural and creative enterprises bring innovations in other sectors due to their marked tendency to cooperate with others. A large number of small enterprises and a high proportion of the self-employed characterize the market segments of cultural and creative industries; cooperation is, therefore, vital for companies' success. It is very useful when creative actors operate in networks and maintain close collaboration and collaborative relationships with suppliers, customers, and demand and supply. Creativity is a vital asset for innovation because innovation essentially involves the successful application of creative ideas. As a result, countries have begun to link the creative industries directly to innovation policy (Dervojeda, Nagtegaal, Lengton, Datta, \& PwC Netherlands, 2013).

\section{Creative Industries and the Other Involvements}

Many policies related to the creative industries have been oriented towards supporting key sectors of content development. Networks and clusters in creative industries' networks are vital sources of innovation. Creative industries' networks also play a key role in linking local and regional places into national and global circuits of information and resources. The places where network connections converge and concentrations of creative industries are found are usually referred to clusters. Clusters have become more important to the new economy, not just as physical locations, but also as nodes in knowledge networks (K. Štofkova \& J. Štofkova, 2010).

All the informal professional networks develop a specific group competence. In these networks, the division of labor, resource allocation, and decision-making are organized through personal contacts. When creative enterprises contribute to the macroeconomic diffusion, comprise not only creative enterprises, but also their suppliers and partners form other sectors in the sense of open innovation and networking.

Arndt et al. (2012), Skippari, Laukkanen, and Salo (2017), Ganesan, George, Jap, Palmatieir, and Weitz (2009), and Mentzer, Min, and Zacharia (2000) mentioned the necessity of collaboration with other supply chain members to engender these innovations. Figure 1 displays the macroeconomic effects of creative industry (Arndt, Freitag, Knetsch, Sakowski, \& Nimmrichter, 2012). 


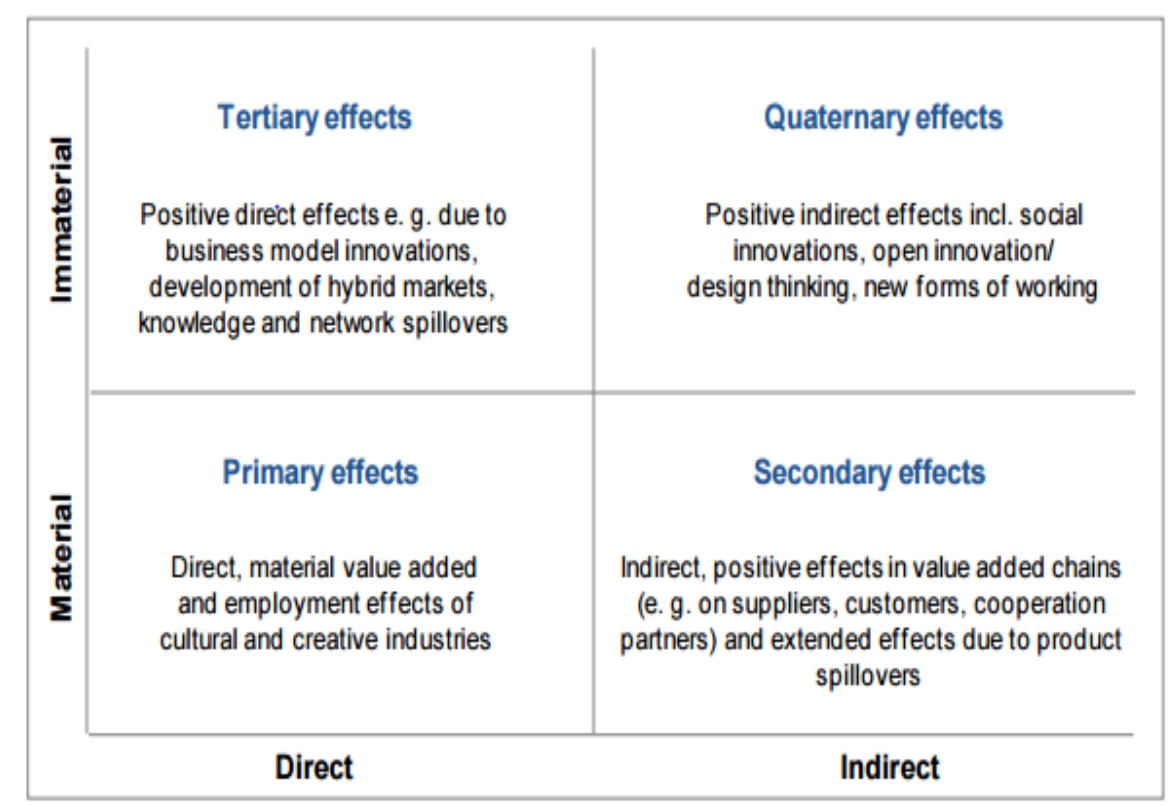

Figure 1. Macroeconomic effects of creative industry

Collaborative innovation involves contributors who share their work of generating a design and also declare the outputs of their individual and collective design efforts to each other (Baldwin \& Von Hippel, 2011). Being a complex, cross-organizational, multidisciplinary activity, and collaborative innovations require interactions across multiple supply chain members (Davis \& Eisenhardt, 2012; Ganesan et al., 2009).

\section{The Literature Review}

Theory describes many approaches dealing with creative industries. All of these approaches try to define the most important factor and strengths and weaknesses of the creative industry approach (Figure 2). The most discussed approach is the sectoral approach, where all jobs in each creative sector are considered to be "creative", even when many functions within these sectors are arguably not creative (such as administrative functions in creative enterprises), while many creative people work outside the formal creative sectors (for example in the design of cars). The more recent employment-based approaches such as the "creative trident" (Cunningham, 2011; Cunningham \& Potts 2013) combines people working in the creative industries and those working in specialist creative jobs in other firms and organizations. Creativity in the commercial creative industries is demonstrated through the branding and packaging of individual talent; following this, the personality cult promoted around stars and celebrities (Flew, 2012). Besides, behind the scenes, the team or the partnership is considered as a more realistic unit of analysis for creative processes and product. The double-act of the genius and the water-carrier are at the core of the creative team. Creative thinking relies upon a union of contrasting capabilities and styles of thinking or playing (Bilton, 2007). Davis \& Scase (2000) have noticed three features of the creative process that make its relationship to organisations complicated: These feature involve autonomy, non-conformity, and indeterminacy.

Autonomy states that individuals engaged in creative processes need to be given considerable scope to exercise independent judgement on how tasks are to be undertaken and organisational goals are to be achieved. Considering non-conformity, since the nature of the 
crative process is that there is no single path to the realisation of goals, individuals engaged in it are often non-conformist in their patterns of work, personal dress codes, and forms of communication. Regardingn determinacy, the goals of the organisation are frequently emergent and arise through the creative process rather than being set in advance of the process. Figure 2 presents the models of the creative industries and associated concepts.

\begin{tabular}{|c|c|c|}
\hline Model & Description & Implications \\
\hline Sectoral Model & $\begin{array}{l}\text { Creative industries are viewed as an economic sector with } \\
\text { distinctive value chain and important economic impact. } \\
\text { The original approach was taken by the United Kingdom. } \\
\text { Many other countries have adopted this approach } \\
\text { including Australia, Canada, and Germany. }\end{array}$ & $\begin{array}{l}\text { A focus on specific sectors that are } \\
\text { relatively easy to identify and measure. May } \\
\text { potentially strengthen the existing divisions } \\
\text { between sectors and inhibit an integrated } \\
\text { approach. }\end{array}$ \\
\hline Concentric Circle Model & $\begin{array}{l}\text { Creative ideas originate in the "core creative arts" and } \\
\text { then disseminate outwards to the "borderline" and } \\
\text { "peripheral" cultural industries. Model originally } \\
\text { developed by Throsby (2001) and extended by The Work } \\
\text { Foundation (2007). Originally used by academics, now } \\
\text { more widely adopted by policy makers. }\end{array}$ & $\begin{array}{l}\text { Identifies the creative content and } \\
\text { "expressive value" involved in different } \\
\text { creative activities and identifies the } \\
\text { symbolic value of creativity. Poses the } \\
\text { problem of adequately defining expressive } \\
\text { value. }\end{array}$ \\
\hline Symbolic Texts Model & $\begin{array}{l}\text { Cultural industries essentially concerned with production } \\
\text { of social meaning through the production and circulation } \\
\text { of texts, mainly used by academics. }\end{array}$ & $\begin{array}{l}\text { Illustrates the very wide scope of creativity, } \\
\text { which includes many functions outside the } \\
\text { cultural industries themselves. }\end{array}$ \\
\hline $\begin{array}{l}\text { Intellectual Property and } \\
\text { Copyright Model }\end{array}$ & $\begin{array}{l}\text { World Intellectual Property Organisation (WIPO) model } \\
\text { of the "copyright industries" involved in the creation, } \\
\text { manufacture, production, broadcast, and distribution of } \\
\text { copyrighted works or intellectual property (IP). Used to } \\
\text { estimate the economic value of the copyright industries. }\end{array}$ & $\begin{array}{l}\text { Allows the value of copyright sales to be } \\
\text { calculated, but not all creative industries } \\
\text { deal with IP, so has limited scope. }\end{array}$ \\
\hline $\begin{array}{l}\text { UNESCO Institute for } \\
\text { Statistics Trade-Related Model }\end{array}$ & $\begin{array}{l}\text { Based on international trade in cultural goods and } \\
\text { services. Used to calculate the export value of trade in } \\
\text { cultural goods. }\end{array}$ & $\begin{array}{l}\text { Provides a clear measure of the export value } \\
\text { of cultural goods and services and therefore, } \\
\text { a useful tool for export-oriented policies. } \\
\text { Provides limited coverage of creative sectors } \\
\text { and does not consider tourism-related } \\
\text { exports. }\end{array}$ \\
\hline Americans for the Arts Model & $\begin{array}{l}\text { Based on the identification of creative sectors related to } \\
\text { the arts. Mainly used as a lobbying tool by the arts sector. }\end{array}$ & $\begin{array}{l}\text { Relates very clearly to arts policy, but } \\
\text { ignores links with technology, computing, } \\
\text { and other creative sectors. }\end{array}$ \\
\hline
\end{tabular}

Figure 2. Models of the creative industries and associated concepts (The 2009 UNESCO framework for cultural statistics, 2009)

Based on the case analysis of creative companies, the 2009 UNESCO framework for cultural statistics statistics (2009) propose a generic culture creative-based value chain which consists of six key components of value creation, namely culture, ideation, design, production, and later on, the culture cycle concept has been developed. The concept of culture cycle was developed to capture the process of value creation within and across these domains and incudes creation -origination and authoring of ideas and content, production - making and production of cultural works, dissemination - distribution of generally mass producible cultural products to consumer and exhibitors, exhibition and reception - provisions of live and/or unmediated experiences to audiences through granting or selling restricted access to consume/participate in often time-based cultural activities, consumption/participation activities of audiences and participants in consuming cultural products and taking part in cultural activities and experiences. Figure 3 exhibits the creative value chain defined by The 2009 UNESCO statistics (2009).

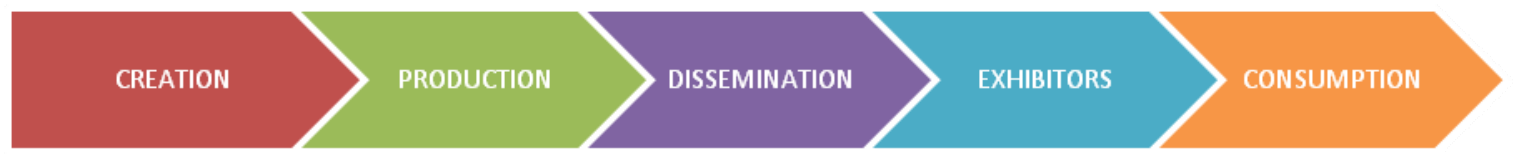

Figure 3. Creative value chain defined by The 2009 UNESCO statistics (2009) 
It is essential to distinguish between the different value chain actors. The groups of actors within the creative industries have been identified. Figure 4 represents the the groups of actors within the creative industries defined by Miles (2009).

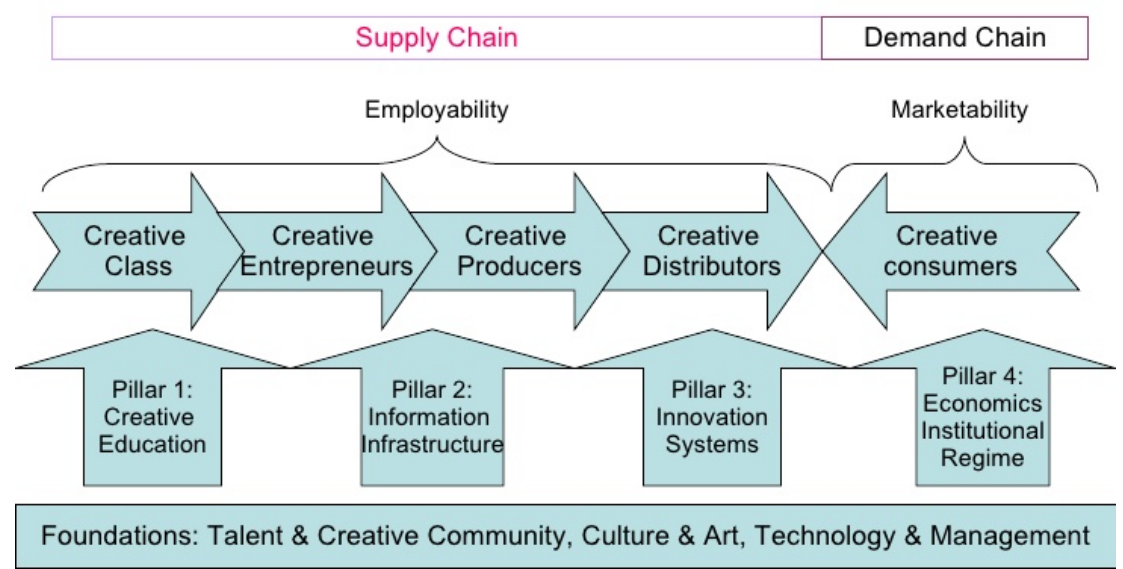

Figure 4. The groups of actors within the creative industries (Miles, 2009)

\section{Method}

The methodology consisted of research activity - mapping the value and supply chains of the creative firms. According to the Statistic Office of the Slovak republic, the creative industries have been defined according to SK NACE codes (Table 1).

Table 1

Creative Industry in the Slovak Republic

\begin{tabular}{|c|c|}
\hline Creative Industry & SK NACE Code/Description \\
\hline Advertising and Marketing & $\begin{array}{l}70210 \text { PR and Communication Activities } \\
73110 \text { Advertising Agencies } \\
73120 \text { Media Representation }\end{array}$ \\
\hline Architecture & 71110 Architectural Activities \\
\hline Design and Fashion Design & 74100 Specialized Design Activities \\
\hline Film, TV, Video, Radio and Photography & $\begin{array}{l}59110 \text { Motion Picture, Video and TV Program Production Activities } \\
59120 \text { Motion Picture, Video and TV program Post-Production Activities } \\
59130 \text { Motion Picture, Video and TV program Distribution Activities } \\
59140 \text { Motion Picture Projection Activities } \\
60100 \text { Radio Broadcasting } \\
60200 \text { TV Programming and Broadcasting } \\
74200 \text { Photographic Activities }\end{array}$ \\
\hline IT, Software and Computer Services & $\begin{array}{l}62010 \text { Computer Programming Activities } \\
62020 \text { Computer Consultancy Activities }\end{array}$ \\
\hline Publishing & $\begin{array}{l}58110 \text { Book Publishing } \\
58120 \text { Publishing of Directories and Mailing Lists } \\
58130 \text { Publishing of Newspapers } \\
58140 \text { Publishing of Journals and Periodicals } \\
58120 \text { Publishing of Computer Games } \\
58290 \text { Other Software Publishing }\end{array}$ \\
\hline Translation and Interpretation Activities & 74300 Translation and Interpretation Activities \\
\hline Music, Performing and Visual Arts & $\begin{array}{l}59200 \text { Sound Recording and Music Publishing Activities } \\
85520 \text { Cultural Education } \\
90010 \text { Performing Arts } \\
90020 \text { Support Activities to Performing Arts } \\
90030 \text { Artistic Creation } \\
90040 \text { Operation of Arts Facilities }\end{array}$ \\
\hline
\end{tabular}


The research focused mainly on music, visual and performing arts of creative industry, fashion design of creative industry, architecture of creative industry, advertisement of creative industry, and ICT of creative industry. Following this, 450 firms operating in these creative industries were studied. The maximum range of errors was around $\pm 9 \%$ and the reliability of research results was about $90 \%$. Primarily, the firms which were the best visible in the individual Slovak regions were interviewed - their names are associated with major projects; firms which cooperate with the Slovak universities in university-practice projects. The method of standardized interview had been chosen as one of the research methods. Even when there had been strict scenario stated in the interview, in some cases, the conversation was free in all cases as well, which reflected the respondent's freedom to express themselves and articulate his/her opinion on an issue. Table 2 shows the creative industry in the Slovak Republic.

Table 2

Value Chain Mechanism

\begin{tabular}{|c|c|c|c|c|c|c|}
\hline $\begin{array}{l}\text { Creative } \\
\text { Field }\end{array}$ & & $\begin{array}{c}\text { Involved } \\
\text { Creative Sector }\end{array}$ & $\begin{array}{c}\text { Creative } \\
\text { Originators }\end{array}$ & $\begin{array}{c}\text { Creative } \\
\text { Enablers/Facilitators }\end{array}$ & $\begin{array}{c}\text { Creative } \\
\text { Distribution } \\
\text { Mechanism } \\
\end{array}$ & $\begin{array}{l}\text { Public Institutional } \\
\text { Involments }\end{array}$ \\
\hline $\begin{array}{c}\text { Music, } \\
\text { Visual and } \\
\text { Performing } \\
\text { Arts }\end{array}$ & $\begin{array}{l}\text { Creative } \\
\text { Original } \\
\text { Producers }\end{array}$ & $\begin{array}{c}\text { Advertising } \\
\text { Publishing } \\
\text { IT } \\
\text { Design } \\
\text { Fashion Design }\end{array}$ & $\begin{array}{l}\text { Screen } \\
\text { Writer, } \\
\text { Choreograph, } \\
\text { Composer, } \\
\text { Producer }\end{array}$ & $\begin{array}{l}\text { Independent } \\
\text { Journalists } \\
\text { Art Photographers } \\
\text { Agents } \\
\text { Publishers } \\
\text { Educational } \\
\text { Institutions }\end{array}$ & $\begin{array}{l}\text { Galery, Museum, } \\
\text { Theatre, Libraty, } \\
\text { Festivals, Concert } \\
\text { Hall... }\end{array}$ & $\begin{array}{l}\text { Sponsors } \\
\text { Profesional Networks } \\
\text { and Associations } \\
\text { Educational Institutions }\end{array}$ \\
\hline $\begin{array}{l}\text { Fashon } \\
\text { Design }\end{array}$ & $\begin{array}{l}\text { Creative } \\
\text { Original } \\
\text { producers }\end{array}$ & $\begin{array}{l}\text { Advertising } \\
\text { Film, TV } \\
\text { Radio and } \\
\text { Photography, } \\
\text { IT, Music, } \\
\text { Performing and } \\
\text { Visual Arts }\end{array}$ & $\begin{array}{l}\text { Fashion } \\
\text { Designer }\end{array}$ & $\begin{array}{l}\text { Employee, who Does: } \\
\text { Sew, Dye, Spin, } \\
\text { Weave, } \\
\text { Cut... }\end{array}$ & $\begin{array}{l}\text { Fashion Salon, } \\
\text { Media, } \\
\text { Fashion } \\
\text { Magazines, } \\
\text { Fashion Show }\end{array}$ & $\begin{array}{l}\text { Beauty Salons } \\
\text { Production Agendy } \\
\text { Modeling agency } \\
\text { Sponsors } \\
\text { Educational Institutions }\end{array}$ \\
\hline Architecture & $\begin{array}{l}\text { Creative } \\
\text { Cervice } \\
\text { Providers }\end{array}$ & IT, Advertising & $\begin{array}{l}\text { Architect, } \\
\text { Customer }\end{array}$ & $\begin{array}{l}\text { Workman } \\
\text { Civil Engineer } \\
\text { Constructor } \\
\text { Urban Planner }\end{array}$ & $\begin{array}{l}\text { Architectural } \\
\text { Studio, } \\
\text { Building } \\
\text { Contractor, } \\
\text { Construction } \\
\text { Company, } \\
\text { Fairtrades }\end{array}$ & $\begin{array}{l}\text { VUC, Associations and } \\
\text { a Councils, } \\
\text { Government Office, } \\
\text { Slovak Chamber of } \\
\text { Architects } \\
\text { Educational Institutions }\end{array}$ \\
\hline Advertising & $\begin{array}{l}\text { Creative } \\
\text { Service } \\
\text { Providers }\end{array}$ & All & $\begin{array}{l}\text { Creative } \\
\text { Employee } \\
\text { Customer }\end{array}$ & $\begin{array}{l}\text { Outsourcers } \\
\text { Media } \\
\text { Production Company }\end{array}$ & $\begin{array}{l}\text { Media } \\
\text { Advertising } \\
\text { Agency }\end{array}$ & $\begin{array}{l}\text { The Slovak Advertising } \\
\text { Standards Council, } \\
\text { The Club of Advertising } \\
\text { Agencies Slovakia, } \\
\text { IAB Slovakia } \\
\text { Educational Institutions }\end{array}$ \\
\hline $\begin{array}{l}\text { IT: Digital } \\
\text { Games } \\
\text { Development }\end{array}$ & $\begin{array}{l}\text { Creative } \\
\text { Content } \\
\text { Producers }\end{array}$ & $\begin{array}{l}\text { Music, } \\
\text { Publishing, } \\
\text { Film, } \\
\text { Photography }\end{array}$ & $\begin{array}{l}\text { Programeer, } \\
\text { Game } \\
\text { Designer, } \\
\text { Screen writer, } \\
\text { Freelancer }\end{array}$ & $\begin{array}{l}\text { Production } \\
\text { Publisher, } \\
\text { Distribution }\end{array}$ & $\begin{array}{l}\text { Production } \\
\text { Company, } \\
\text { Publishing } \\
\text { Media and New } \\
\text { Media } \\
\text { Shops and e-shops } \\
\text { PC Magazines }\end{array}$ & $\begin{array}{l}\text { Industrial Property } \\
\text { Office of the Slovak } \\
\text { Republic, } \\
\text { Educational Institutions }\end{array}$ \\
\hline
\end{tabular}

\section{Results}

Value chains within creative industries are often diverse and complex without a strong organizing entity. Figure 5 exhibits the involved creative sector. 


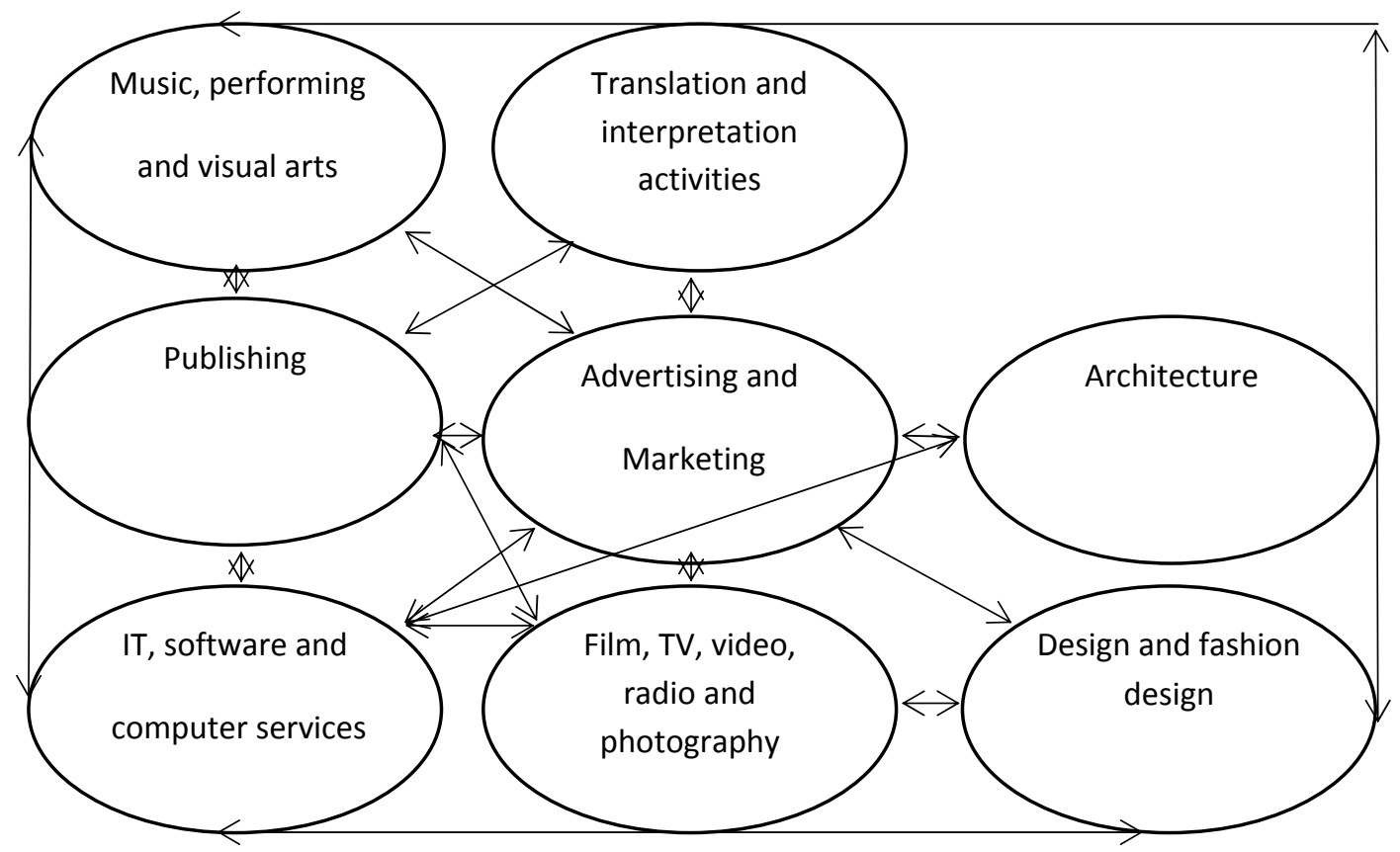

Figure 5. Involved creative sector

The value added scale and the relationship of the value and supply chains differs. This difference is based on the creative industry and the character of the creative activity (creative original produce or creative service provider). Even when the creative sectors act independently on the market, some creative sectors are involved in the other creative sector (Table 2 and Figure 5). Creative industries comprise a variety of subsectors. Creators of the creative product are creative originators, who through creative enablers/facilitators disseminate and distribute the creative product to customer.

Very important role in the value chain pay the key public institutional involvements. These actors can also build up stakeholders' groups including industry associations, regional development agencies, chambers of commerce, municipalities, business networks, and educational institutions. All these networks should promote a conductive creative environment. Nowadays, it is very important for creative firms to have not only different competencies but also to have creators, distributors, and technological professionals as well. The supply chain generally consists of creation, production, dissemination, and exhibition, and consumption. Very special cases of the creative industries are the advertising and architecture creative industries. In these industries, the first impulse of the creative idea generation is the customer. Moreover, the creative industry value chains are often complex without a strong organizing entity.

\section{Discussion and Conclusion}

There are expected economic impacts and creation of employment in all steps of the value chain from the customer part to the final market part, in other words, from the creative process consumption. Figure 6 displays the the value chain logic in supply chain relationships. 


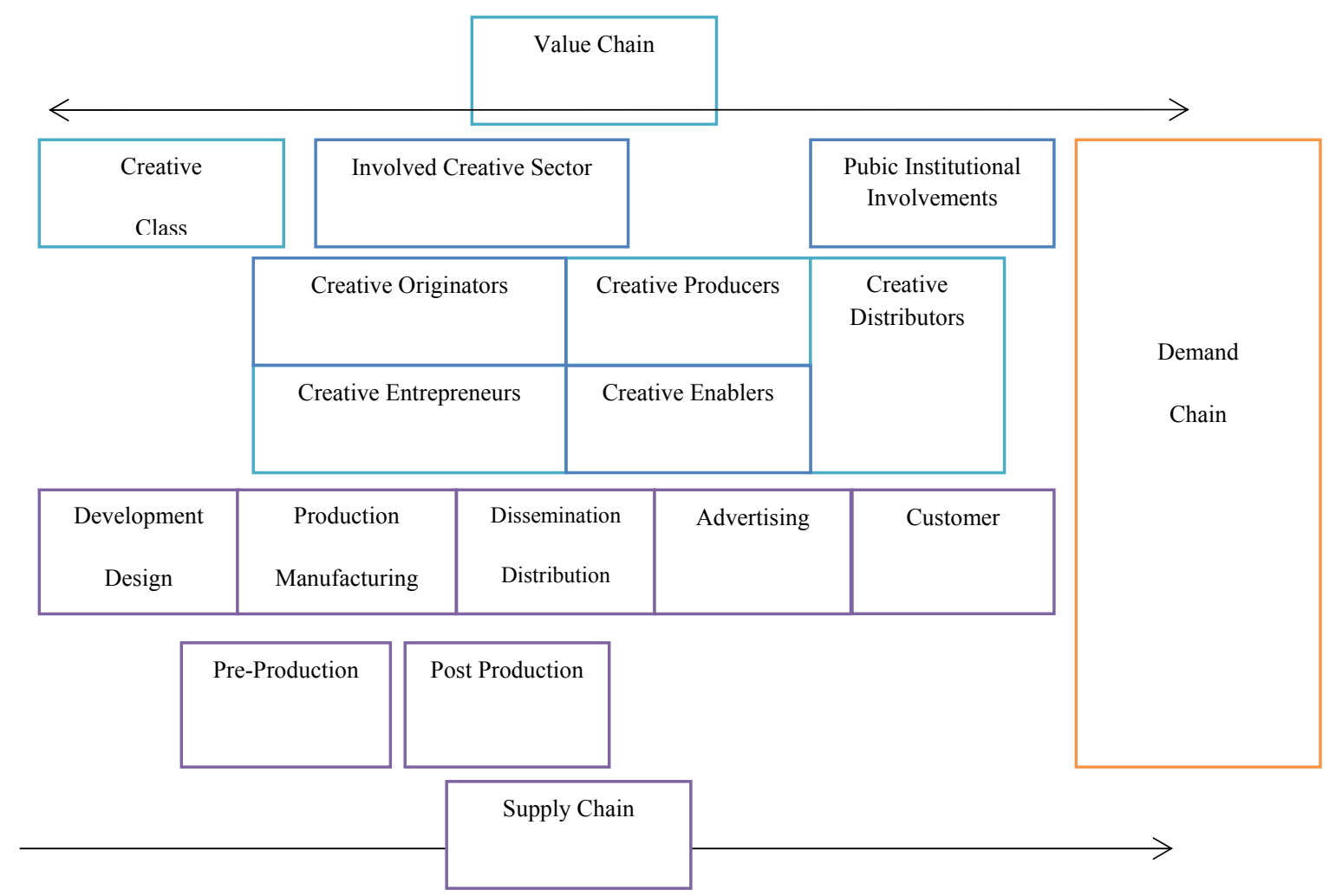

Figure 6. The value chain logic in supply chain relationships

For example, creative industries generate work opportunities for logistic and transport companies, when selling the creative products, as well as bringing economic spillovers to other sectors, for example, by sourcing cotton fabric for the production of some art crafts and fashion.

Strategic alliances and joint ventures becomes increasingly important for creative industry as well. Knowledge is transferred among partners in the network and thereby, the importance of partnership in the chain increases since it allows maximizing the value and optimally overcomes business challenges. Critical mass of each of the value, supply, and demand chain actors is necessary condition for creative industries growth. Building a critical mass of supply chain actors can be helpful in the emergence of creative industries within a region. Moreover, creative industry value chains are often complex without a strong organizing entity (Figure 6).

Value chain activities can be performed by one or more regions or countries. Valuechain can be fragmented so that various activities can be carried out in various companies, often in different regions and countries. Individual firms may provide only selected activities of the value chain.

This paper has proposed how value chain can be adapted to include additional perspectives which reflect the differentiation of the market. The development of value chain should identify business opportunities to create shared value between business and society. Adopting the value chain will allow firm strategy to be more widely applicable and more relevant in business scenarios and strategies.

Each part of the value chain is the source of uniqueness in the process of providing services. Due to the competitive struggle and strength of competitors, any change can affect the added value and strengthen the competitive position at the market. All the factors 
mentioned in this paper have an impact on the company economic profit and its decision to remain in this sector.

\section{References}

Arndt, O., Freitag, K., Knetsch, F., Sakowski, F., \& Nimmrichter, R. (2012). The cultural and creative industries in the macroeconomic value added chain. Retrieved from http://www.isi.fraunhofer.de/isi-wAssets/docs/t/en/Engl_KurzfassungKKW-Wertschoepfungskette.pdf

Baldwin, C., \& Von Hippel, E. (2011). Modeling a paradigm shift: From producer innovation to user and open collaborative innovation Organization. Science, 22(6), 1399-1417.

Bilton, C. (2007). Management and creativity: From creative industries to creative managament. Malden, MA: Blackwell Publishing.

Cunningham, S. (2011). Developments in measuring the creative workforce. Cultural Trends, 20(1), 25-40.

Cunningham, S., \& Potts, J. (2013). Creative industries and the wider economy. In C. Jones, M. Lorenz, \& J. Sapsed (Eds), Handbook of creative industries (pp. 387-404). Oxford: Oxford University Press.

Davis, H., \& Scase, R. (2000). Managing creativity: The dynamics of work and organization. Buckingham: Open University Press.

Davis, J. P., \& Eisenhardt, K. M., (2012). Rotating leadership and collaborative innovation recombination processes in symbiotic relationships. Administrative Science Quarterly, 56(2), 159-201.

Dervojeda, K., Nagtegaal, F., Lengton, M., Datta, P., \& PwC Netherlands. (2013). Creative industries Analysis of industry specific framework conditions relevant for the development of world - class clusters (pp. 20-66, Rep. No. 71/PP/ENT/CIP/11/N04C031). Brussels, Belgium: European Union.

Eikhof, D., \& Haunschild, A. (2007). For art's sake! Artistic and economic logics in creative production. Journal of Organizational Behaviour, 28(5), 523-538.

Flew, T. (2012). Creative Suburbia: Rethinking urban cultural policy - The Austrailan case. International Journal of Cultural Studies, 15(3), 231-246.

Ganesan, S., George, M., Jap, S., \& Palmatier, R., Weitz, B. (2009). Barton supply chain management and retailer performance: Emerging trends, issues, and implications for research and practice. Journal of Retailing, 85, 84-94.

Plangger, K. (2016). Thriving in a New World Economy Proceedings of the 2012 World Marketing Congress/Cultural Perspectives in Marketing Conference. Cham: Springer International Publishing.

Mentzer, J. T., Min, S., \& Zacharia, Z. G. (2000). The nature of interfirm partnering in supply chain management. Journal of Retailing, 76(4), 549-568.

Miles, I. (2009). Innovation, convergence and creative (service) industries. Paper presented at MOSTI - Service innovation seminar in Manchester Institute of Innovation Research. Retrieved from http://www.slideshare.net/IanMiles/creativeindustries-innovation-and-digital-convergence

Tourism and the Creative Economy. (2014). OECD Publications Centre.

Skippari, M., Laukkanen, M., \& Salo, J. (2017). Cognitive barriers to collaborative innovation generation in supply chain relationships. Industrial Marketing Management, 62, 108-117.

Štofko, S., Šoltés, V., \& Štofková, Z. (2015). Options of using the integrated management system. Production Management and Engineering Sciences, 267-272. doi:10.1201/b19259-49

Štofková, J., Madleňák, R., \& Štofková Repková, K. (2015). Business Management. DOLIS

Štofková, K, \& Štofková, J. (2010). EduLearn 10: International Conference on Education and New Learning Technologies: 5th-7th July, 2010, Barcelona, Spain: publications. Valencia, Spain: International Association of Technology, Education and Development (IATED).

The 2009 UNESCO framework for cultural statistics (FCS) (2009). Montreal: UNESCO Institute for Statistics.

Davis, H., \& Scase, R. (2000). Managing creativity: The dynamics of work and organization. Buckingham: Open University Press. 